\title{
ERRATUM
}

Hee Jin Kim · Barbara A. Triplett

\section{Cotton fiber germin-like protein. I. Molecular cloning and gene expression}

Published online: 27 March 2004

(C) Springer-Verlag 2004

\section{Planta (2004) 218:516-524}

Owing to problems during data transfer, Table 1 contained errors. The correct version is given below.

Table 1 Proposed enzymatic activities or physiological functions of germins and germin-like proteins (GLPs). Classification of three subclasses was done by Khuri et al. (2001). Oxo Oxalate oxidase;

$E C M n-S O D$ extracellular manganese superoxide dismutase, $A B P$ auxin binding protein, AGPPase ADP glucose pyrophosphatase/ phosphodiesterase

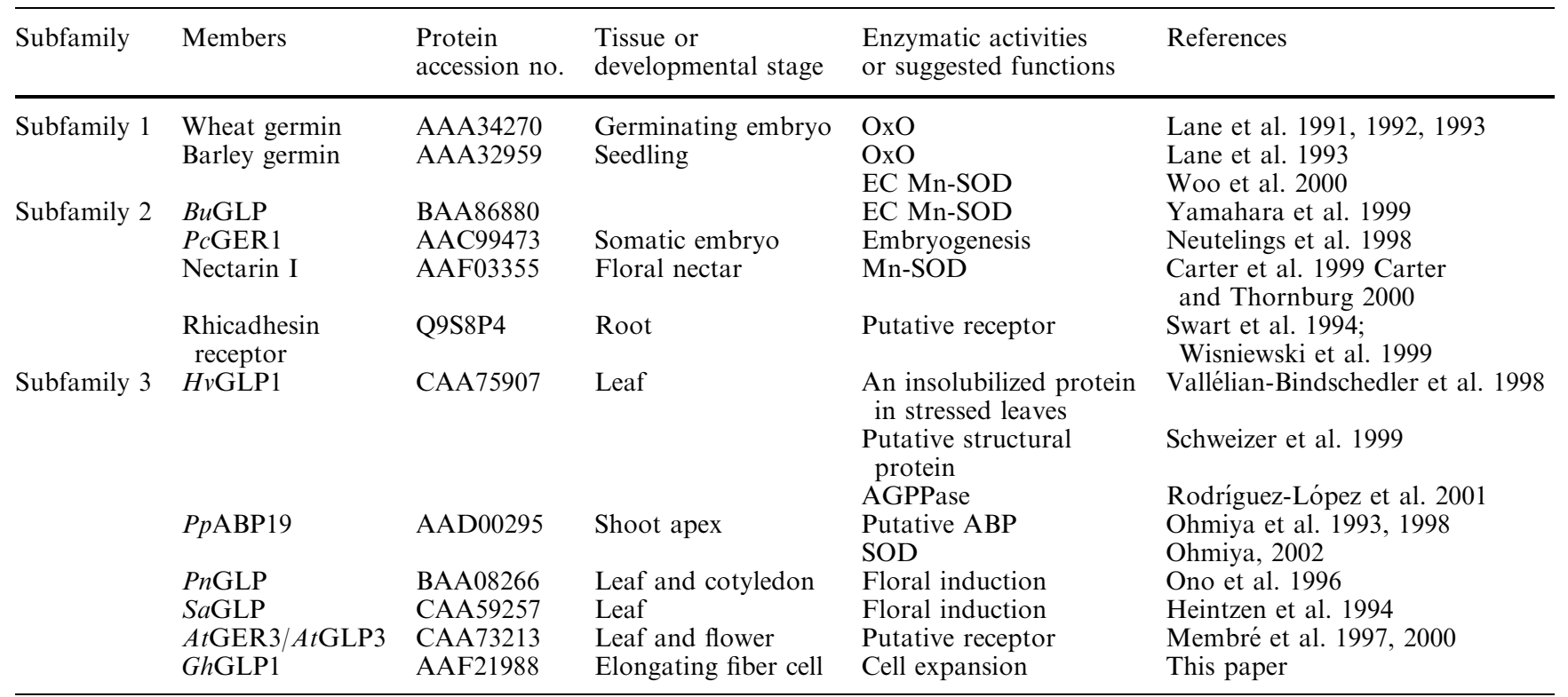

The online version of the original article can be found at http:// dx.doi.org/10.1007/s00425-003-1133-1

H. J. Kim · B. A. Triplett $(\square)$

Southern Regional Research Center, USDA,

ARS New Orleans, LA 70124, USA

E-mail: btriplet@srrc.ars.usda.gov

Tel.: + 1-504-2864275

Fax: + 1-504-2864419 